\title{
What Influences Urbanites' Mobile Payment Adoption? The Moderating Roles of Demographic Divides
}

\author{
Ong Choon Hee*, Koo Nyuk Ying, Tan Owee Kowang and Lim Lee Ping \\ Azman Hashim International Business School, Universiti Teknologi Malaysia, Johor Bahru 81310 , \\ Johor, Malaysia
}

\begin{abstract}
This study examines the moderating roles of demographic divides, such as gender, income, and education, on factors influencing mobile payment adoption among urbanites in Malaysia. An online survey questionnaire was used for data collection, which yielded 428 responses. PLS-SEM was employed to assess validity, reliability, hypothesis testing, and PLS-MGA of the study constructs. The findings of this paper revealed that perceived security, perceived ease of use, perceived usefulness, and trust were significantly related to mobile payment adoption. Gender, income, and education were found to moderate the results. This research provides important information to service providers, banking institutions, and the government to understand factors influencing mobile payment adoption and consider demographic characteristics

ARTICLE INFO

Article history:

Received: 4 October 2019

Accepted: 9 June 2020

Published: 25 December 2020

DOI: https://doi.org/10.47836/pjssh.28.4.42

of gender, income, and education in mobile payment adoption. This study explains the moderating effects of demographic divides on mobile payment adoption among urbanites that are rarely addressed in Malaysia.
\end{abstract}

E-mail addresses:

ongchoonhee@gmail.com (Ong Choon Hee)

eeink.yuying@gmail.com (Koo Nyuk Ying)

oktan@utm.my (Tan Owee Kowang)

leeping638@gmail.com (Lim Lee Ping)

*Corresponding author
Keywords: Demographic divides, mobile payment adoption, technology adoption factors, urbanites 


\section{INTRODUCTION}

Smartphones can perform multiple functions like navigating websites, monitoring body fitness, purchasing goods, shopping online, paying bills, and many others. E-wallets and mobile payments are inexorable, although most Malaysians seem unwilling to accept the idea of going out without cash. Mobile payments are the norm in countries like China, Japan, and Korea. Around 90\% of business transactions in China use mobile payments, but the opposite is true in Malaysia even though the government encourages the public to forego cash for e-wallets (Martin, 2019). The Central Bank is making extensive efforts to transform Malaysia into a cashless society. For instance, the Central Bank has authorized 49 non-banking companies to provide e-money services: 39 via e-wallet and 10 via online accounts or cards (Martin, 2019). Notable mobile payment or e-wallet platforms in Malaysia include Touch n'Go, GrabPay, and Boost ("Fitch Solutions", 2019). However, efforts should not only come from making cashless payment channels available but also to understand why people remain hesitant to use mobile payments instead of cash and physical wallets. Although mobile payment is the way of the future, Malaysian urbanites are not embracing the technology. As of June 2019, there were only 4.4 million users out of 32.66 million, or $13.5 \%$ of the total population, who were using mobile payment (Martin, 2019). These statistics do not come close to the likes of Japan, Korea, and China (Chua et al., 2020). Compared to the number of mobile phone users, the number of mobile payment subscribers is still considerably low in Malaysia (Rehman \& Zabri, 2020). For mobile payment to succeed, issues and concerns about security, trust, and usability among the users must be addressed. In addition, social disparity is still noticeable, leading to a digital divide or digital inequality. A digital divide is inevitable in any form of technology adoption in any country, and it seems to perpetuate, although we assume there should be no gap or inequality of technology adoption in this digital era (Rahman, 2015). For instance, the demographic divide persists, especially in terms of different individual characteristics among urbanites. A demographic divide is acknowledged as a major barrier to using mobile payments (Rahman, 2015). In Asian countries, demographic factors, such as gender, income, and education are regarded as important indicators of the nation's success in technology adoption (Quibra et al., 2003). Recognizing that demographic divide is critical to the success of mobile payment adoption. This paper intends to test the moderating roles of demographic factors toward mobile payment adoption among Malaysian urbanites so appropriate marketing strategies can be designed and implemented.

\section{Theoretical Background and Hypothesis Development}

The Technology Acceptance Model (TAM) and Unified Theory of Acceptance and Use of Technology (UTAUT) are among prominent mobile payment adoption theories. The TAM, established by Davis 
(1989), is the most accepted model for measuring an individual's acceptance and usage of technology. TAM was originally built on the theory of reasoned action and introduced two factors, perceived usefulness and perceived ease of use, in specific information system (IS) usage (Surendran, 2012). Perceived usefulness and perceived ease of use are both related to IS adoption behaviors. According to TAM, both factors will lead prospective users to use the actual system eventually. Nevertheless, various researchers have attempted to add new determinants, on top of perceived usefulness and perceived ease of use, to take a more appropriate approach to testing the model according to specific research settings. Past studies, including Chau (1996), Hu et al. (1999), Cheng (2011), and EscobarRodriguez et al. (2012) had used TAM extensions (Davis et al., 1989), like TAM 2 (Venkatesh \& Davis, 2000) and TAM 3 (Venkatesh \& Bala, 2008) to explain users' intentions to use new technology. Apart from that, the UTAUT was further established by Venkatesh et al. (2003) to integrate the construction of all theories and formed a unified view since there were several similar constructions (Dwivedi et al. 2011). Many researchers have applied the UTAUT theory to understand the users' attitudes toward technology adoption (Rahi \& Abd Ghani, 2018). The UTAUT model introduces four moderators (voluntariness, experience, gender, and age) and four determinants, namely, effort expectancy, performance expectancy, facilitating condition, and social influence. It emphasizes the roles of demographic moderators in explaining the variance of technology adoption (Venkatesh et al., 2003). From the discussion above, the two theories show that, even though some factors were critically related to technology adoption, the demographic divide issue has become a discussion topic for many researchers and policy makers when it comes to technology adoption (Rahman, 2015). Therefore, this study attempts to combine both theories of TAM and UTAUT to identify significant determining factors and moderators of the mobile payment adoption research framework.

Adoption of Mobile Payment. The growth of digital technology has led to the existence of various online payment systems. Mobile payment has received much attention with the emergence of e-environments. Mobile payment is defined as using mobile phones, equipped with necessary functions and applications, to enable moving of funds from the registered user's account to the payment account ( $\mathrm{Ng} \&$ Yip, 2010). Generally, the transaction is carried out via mobile applications provided by authorized service providers (Wang et al., 2013). Although mobile payment has been a topic of discussion since it was first introduced to the market, the adoption rate is not as high as expected. According to Martin (2019), those who use mobile payments only constitute about $13.5 \%$ of the total population in Malaysia. Nevertheless, it is predicted that mobile payment's market influence will increase in years to come (Schierz et al., 2010). Like it or not, the 
cashless lifestyle is going to replace the traditional lifestyle massively. Therefore, understanding a broader perception of mobile payment adoption in Malaysia will certainly help all participants of the mobile payment ecosystem, such as developers, operators, vendors, and governments, design sustainable strategies to stay competitive in the market (Yap \& Ng, 2019).

Perceived Usefulness. TAM is the main theory that has been widely used to explain the acceptance of new technology (Davis et al., 1989). TAM emphasizes users' behavioral and attitudinal intentions to uptake a new technology (Chanchai et al., 2016). Perceived usefulness is the key construct of TAM for analyzing user acceptance of the new payment technology (Susanto et al., 2016). In the context of mobile payment, perceived usefulness is operationally defined as how individuals believe mobile payment technology will enhance their payment transactions (Chanchai et al., 2016). Perceived usefulness will be low if individuals do not understand how mobile payment could be a more effective way to achieve payment outcomes. Teoh et al. (2013) found that a user's inclination to use mobile payment was highly influenced by perceived usefulness, especially in attaining task-related objectives. Likewise, Ramayah and Suki (2006), Chua et al. (2020) provided evidence that perceived usefulness was significantly related to the adoption of various technologies inclusive of mobile payment. Therefore, the following is hypothesized:
H1: There is a significant positive relationship between perceived usefulness and mobile payment adoption.

Perceived Ease of Use. Perceived ease of use is understood as the extent to which users believe that using mobile payment is easy and free of mental stress (Chua et al., 2020). Ndubisi and Jantan (2003) gave evident explanations that mobile payment users should communicate with the system and felt comfortable to conduct transactions. If the mobile payment service is tedious and troublesome, the perceived ease of use will be low. For example, if the application requires consumers to provide lots of information while processing transactions, consumers may perceive it as difficult to use. To facilitate users with the ease of use concept, a simple design should be created, with clear function keys and symbols on the mobile payment interface (Pagani \& Schipani, 2008). Consequently, these ease of use concepts will attract more non-users to adopt mobile payment in the future. A study of Wang and Li (2011) has proven that the adoption rate will be higher when the mobile technology is easier to use. Further, Davis (1989) explained that, even though users understood the usefulness of mobile payment, the trouble with using mobile payment might stop them from using it. Therefore, if we can create simple applications and fit into the model of mobile payment, it will increase the adoption of mobile payment (Venkatesh, 2000). For instance, mobile payment should allow one click pay without having 
to enter details or provide passcodes for each transaction (Singh, 2019). Based on the above discussion, the following is hypothesized:

H2: There is a significant positive relationship between perceived ease of use and mobile payment adoption.

Perceived Security. Perceived security is defined as the extent where users believe using online mobile payment is secure (Vijayasarathy, 2004). It usually points to the subjective evaluation of mobile payment security (Linck et al., 2006). While mobile payment technology is emerging, Chen (2008) claimed that users still had concerns over security issues such as confidentiality, authentication, authorization, integrity, and non-repudiation. Generally, users are sensitive when it comes to the involvement of personal information, especially when cybersecurity threats continue to lurk on the horizon. Users will decline to use mobile payment if they perceive the level of the security features is low (Tsiakis \& Sthephanides, 2005). Kurnia and Benjamin (2007) provided evidence that users' security concerns influenced their adoption of mobile payment. When users encounter security breaches during online transaction, they would reject the usage of a mobile payment system. Past studies (Khraim et al., 2011; Tsiakis \& Sthephanides, 2005) had looked into the relationship between perceived security and user acceptance of mobile payment. It was found that perceived security was a significant driver of user's mobile payment adoption, especially when digital service providers provided extra security to keep the users' money secured from unauthorized access (Singh, 2019; Teoh \& Md Nor, 2007). Hence, the following is hypothesized:

H3: There is a significant positive relationship between perceived security and mobile payment adoption.

Trust. Trust is explained as a cognitive process, where a person develops trustworthiness and willingness to conduct a payment transaction over the mobile network without having to monitor the mobile payment processes (Yang et al., 2015). Generally, users believe the network service provider is able to provide secure service and expect the online transaction to fulfill its obligations (Cao et al., 2018). However, owing to the presence of uncertainties, payment risks, and privacy and security issues, trust has become a significant factor for users to engage in mobile payment. Teoh et al. (2013) opined that users were generally inclined to use online payment from a trusted service provider. Gefen (2000) further explained that customer's trust in the mobile transaction was important because there was little guarantee that personal data and transaction activity were protected. Transactions conducted over the mobile network are vulnerable and at greater risk. While conducting transactions, customers pay for the services and want their personal information to be protected (Zhou, 2011). Customers with high trust levels 
over the service provider will use the online mobile payment without fear. Conversely, those with low trust levels will refrain from using it. Previous research, such as Chen and Barnes (2007), had reported that trust had a significant positive relationship with mobile payment adoption. Likewise, Dastan and Gürler (2016) concurred that trust had a positive impact on the adoption of mobile payment, and this notion was also endorsed by Mahad et al. (2015). In short, trust is an essential factor that is able to influence the usage of mobile payment systems (Mondego $\&$ Gide, 2018). Hence, the following is hypothesized:

H4: There is a significant positive relationship between trust and mobile payment adoption.

\section{The Moderating Roles of Demographic}

Divides. According to Venkatesh et al. (2003), demographic variables are important factors to stimulate the adoption of new technology. Previous researchers, like Wei et al. (2009) found that gender was a significant moderator in technology adoption. Rosen and Maguire (1990) discovered that women generally had a higher level of information technology anxiety. Men and women were perceived to process information using different cognitive structures to make decisions (Bem, 1981). Therefore, gender plays a significant role in adopting new technology (Venkatesh \& Morris, 2000; Yu, 2012). Recently, income has started to gain more attention in studies of online payment. According to Shiveen and Rahela (2017), income determines consumers' spending ability. They postulated that high income group users were more likely to make online transactions than low income group users. Nevertheless, Mossberger et al. (2006) and Jung et al. (2001) introduced the role of education in technology adoption. The researchers explained that consumers with higher education levels might possess better understanding in using mobile technology. They are in a better position to adopt mobile payments than the lower education group users (Abeer et al., 2015). Thus, based on the above discussion, the following hypotheses are established:

H5a: Gender moderates the relationship between perceived usefulness, perceived ease of use, perceived security, trust, and mobile payment adoption.

H5b: Income moderates the relationship between perceived usefulness, perceived ease of use, perceived security, trust, and mobile payment adoption.

H5c: Education moderates the relationship between perceived usefulness, perceived ease of use, perceived security, trust, and mobile payment adoption.

Research Model. In this study, the proposed research model was established based on the viewpoints from the literature review that link the determining factors, moderating variables (gender, income, education), and mobile payment adoption. The research model is depicted in Figure 1. 


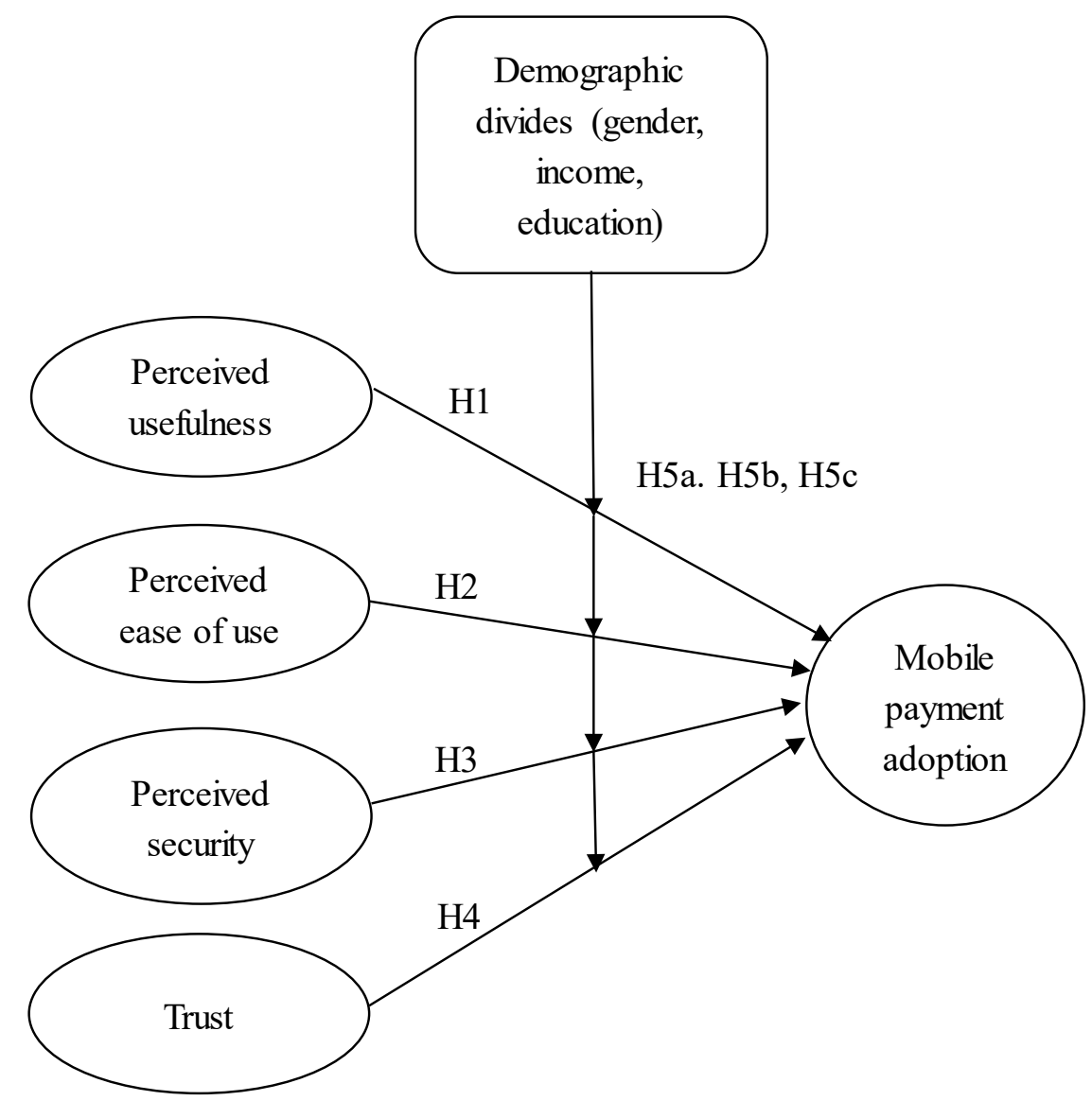

Figure 1. Research model

\section{METHODOLOGY}

\section{Population and Sampling Method}

The targeted population of this study was urbanites who lived in Malaysia. According to the Department of Statistics Malaysia (2019), there are approximately 32.66 million people living in Malaysia. Urbanites constitute 24.4 million of the population. Hair Jr. et al. (2017) suggested that the minimum sample size for a PLSSEM research could be determined based on Cohen's (1992) four factors sampling criteria: a) the statistical power, b) the significance level, c) the smallest $\mathrm{R}^{2}$ value expected, and d) the number of arrows pointing at the target construct. It is common for social science research to be conducted with a statistical power of $80 \%$, a significance level of $5 \%$, and an $\mathrm{R}^{2}$ value of 0.25 (Wong, 2013). In accordance with the above criteria, the minimum required sample size for a research model of 4 arrows 
pointing at a target construct is 65 . In this study, the researchers used a judgmental sampling method to obtain the samples from the cities of Kuala Lumpur and Johor Bahru. Judgmental sampling method was used because it was the researchers' purpose to select mobile users who lived in these cities (Saunders et al., 2009). The reason for selecting Kuala Lumpur and Johor Bahru as the research sites is that they are the first and second largest urban areas in Malaysia (Tey et al., 2019).

\section{Measures}

Measures for the study constructs were adapted from previous studies. Details of the measures are shown in the Appendix. A fivepoint Likert scale was used to indicate the level of agreement among the respondents.

\section{Data Collection Procedure}

This research used an online survey questionnaire to collect data and employed cross-sectional research approach. Data collection was conducted via a pilot study and actual field study. Online survey forms were delivered to the respondents via emails and social networking sites. Respondents were selected based on their current residing locations in Kuala Lumpur and Johor Bahru. Completed questionnaires were collected via online platforms and data was prepared for subsequent analysis.

\section{Pilot Study}

A sample size of 30 was randomly selected to conduct a pilot test prior to the field research on a larger sample size. The pilot study results showed that the reliability coefficients were above 0.7 and considered reliable to proceed with mass data collection (see Table 1). The online survey questionnaire was then distributed to the respondents; 428 responses were obtained, and PLS-SEM was used to test the research hypothesis.

Table 1

Reliability coefficients for the pilot study

\begin{tabular}{llll}
\hline Constructs & Number of items & Cases valid & Cronbach's Alpha \\
\hline MP & 6 & 30 & 0.848 \\
PU & 6 & 30 & 0.848 \\
PE & 6 & 30 & 0.780 \\
PS & 6 & 30 & 0.945 \\
T & 6 & 30 & 0.906 \\
\hline
\end{tabular}

Notes: $\mathrm{n}=30$ 


\section{RESULTS}

\section{Profile of the Respondents}

The survey participants included 175 male respondents and 253 female respondents. Most respondents possessed a bachelor's degree $(65.7 \%)$. Another $14.5 \%$ of the respondents possessed a Master's degree while others were having a Diploma
$(10.3 \%)$, a certificate $(8.9 \%)$, or a Doctoral degree $(0.7 \%)$. Given the urbanite samples, most respondents $(40.4 \%)$ were reported to have a monthly income of RM3001RM5000, whereas $7.5 \%$ of the respondents were earning below RM1000 per month. Details of their demographic profiles are shown in Table 2.

Table 2

Profile of the respondents

\begin{tabular}{lll}
\hline Description $(\mathrm{n}=428)$ & Frequency & Percentage \\
\hline Gender & 175 & 40.9 \\
Male & 253 & 59.1 \\
Female & & \\
Education & 38 & \\
SPM Certificate & 44 & 8.9 \\
Diploma & 281 & 10.3 \\
Bachelor's Degree & 62 & 65.6 \\
Master's Degree & 3 & 14.5 \\
Doctoral Degree & & 0.7 \\
& & \\
Income & 32 & 7.5 \\
RM1000 and below & 122 & 28.5 \\
RM1001-RM3000 & 173 & 40.4 \\
RM3001-RM5000 & 101 & 23.6 \\
RM5000 and above & & \\
\hline
\end{tabular}

\section{Measurement Model Assessment}

A two-step approach, recommended by Chin (2010), was used to assess this study's measurement and structural model. First, we examined the measurement model by assessing indicator reliability, composite reliability, convergent validity, and discriminant validity. The values of indicator reliability and composite reliability were all above 0.7 , indicating that they were reliable. 
Next, convergent validity was evaluated by loading value. Other loadings of the study examining the outer loadings and average constructs were higher than 0.7 and the variance extracted values (AVEs). Those AVEs were above 0.5; thus, convergent with outer loadings lower than 0.7 were validity of the model was established removed from the list of the indicators. (Hair Jr. et al., 2017). The results of the An indicator (PE2) was deleted due to low measurement model are shown in Table 3.

Table 3

Results of the measurement model

\begin{tabular}{|c|c|c|c|c|c|}
\hline Constructs & Indicators & Loadings & $\begin{array}{l}\text { Cronbach's } \\
\text { Alpha }\end{array}$ & $\begin{array}{l}\text { Composite } \\
\text { Reliability }\end{array}$ & AVE \\
\hline \multirow[t]{6}{*}{ MP } & MP1 & 0.881 & 0.941 & 0.953 & 0.772 \\
\hline & MP2 & 0.861 & & & \\
\hline & MP3 & 0.885 & & & \\
\hline & MP4 & 0.903 & & & \\
\hline & MP5 & 0.848 & & & \\
\hline & MP6 & 0.895 & & & \\
\hline \multirow[t]{5}{*}{$\mathrm{PE}$} & PE1 & 0.824 & 0.875 & 0.909 & 0.668 \\
\hline & PE3 & 0.884 & & & \\
\hline & PE4 & 0.871 & & & \\
\hline & PE5 & 0.787 & & & \\
\hline & PE6 & 0.709 & & & \\
\hline \multirow[t]{6}{*}{ PS } & PS1 & 0.821 & 0.926 & 0.942 & 0.730 \\
\hline & PS2 & 0.883 & & & \\
\hline & PS3 & 0.868 & & & \\
\hline & PS4 & 0.867 & & & \\
\hline & PS5 & 0.824 & & & \\
\hline & PS6 & 0.863 & & & \\
\hline \multirow[t]{6}{*}{ PU } & PU1 & 0.852 & 0.919 & 0.937 & 0.711 \\
\hline & PU2 & 0.894 & & & \\
\hline & PU3 & 0.846 & & & \\
\hline & PU4 & 0.868 & & & \\
\hline & PU5 & 0.831 & & & \\
\hline & PU6 & 0.763 & & & \\
\hline
\end{tabular}


Table 3 (Continued)

\begin{tabular}{llllll}
\hline Constructs & Indicators & Loadings & $\begin{array}{l}\text { Cronbach's } \\
\text { Alpha }\end{array}$ & $\begin{array}{l}\text { Composite } \\
\text { Reliability }\end{array}$ & AVE \\
\hline $\mathrm{T}$ & $\mathrm{T} 1$ & 0.834 & 0.929 & 0.944 & 0.737 \\
& $\mathrm{~T} 2$ & 0.861 & & & \\
$\mathrm{~T} 3$ & 0.849 & & & \\
& $\mathrm{~T} 4$ & 0.886 & & & \\
$\mathrm{~T} 5$ & 0.873 & & & \\
& $\mathrm{~T} 6$ & 0.847 & & & \\
\end{tabular}

To assess discriminant validity of (Henseler et al., 2014). According to Table the constructs, Heterotrait-Monotrait 4, discriminant validity between any pair of Ratio of Correlations (HTMT) was used. the study constructs was established since The HTMT criterion is a relatively new all the HTMT values displayed were below approach to assessing discriminant validity 0.90 (Hair Jr. et al., 2017).

Table 4

Heterotrait-Monotrait Ratio (HTMT) analysis

\begin{tabular}{llllll}
\hline & MP & PE & PS & PU & TR \\
\hline MP & & & & \\
PE & 0.688 & & & \\
PS & 0.560 & 0.414 & & \\
PU & 0.760 & 0.758 & 0.329 & & \\
TR & 0.683 & 0.568 & 0.762 & 0.501 \\
\hline
\end{tabular}

Notes: Discriminant validity was established at HTMT $<0.90$

\section{Collinearity Assessment}

Collinearity assessment is necessary to ensure all the research model's path coefficients are not biased before structural model assessment is conducted. According to the variance inflation factor (VIF) guidelines, it is acceptable if the VIF values for the predictor constructs are less than 5 , and the tolerance values stay above 0.2 . Table 5 indicates that all the VIF values were lower than 5 and the tolerance levels were above 0.2 , thus providing evidence of non-collinearity. 
Table 5

Collinearity assessment

\begin{tabular}{llll}
\hline Predictor Constructs & Tolerance & VIF & Target Construct \\
\hline PE & 0.469 & 2.132 & MP \\
PS & 0.495 & 2.020 & \\
PU & 0.501 & 1.995 & \\
T & 0.411 & 2.432 & \\
\hline
\end{tabular}

Notes: VIF: Variance Inflation Factor

\section{Common Method Bias}

To examine whether common method bias exists in this study, a collinearity test, suggested by Kock (2015), was conducted. The existence of a VIF greater than 3.3 was proposed as an indication of pathological collinearity, and also a sign to indicate that the model might be contaminated by common method bias. According to Table 5, all VIFs resulting from the collinearity test were lower than 3.3. Hence, the model is considered free of common method bias (Kock, 2015).

\section{Structural Model Assessment}

In the present study, the research model was tested, with 428 cases with subsamples of 5000 to estimate the significance of path coefficients using a bootstrapping procedure (Preacher \& Hayes, 2008). The predictor constructs could explain $65.2 \%$ $\left(R^{2}=0.652\right)$ of the total variance of mobile payment adoption. The coefficient of determination $\left(\mathrm{R}^{2}\right)$ is considered moderate in this case (Hair Jr. et al., 2017). The hypothesis testing results showed that all the path coefficients were significant at the level of $1 \%(p<0.01)$ (see Table 6 and Table 7). The lower and upper values of the confidence interval $(95 \%)$ indicate that the value 0 (zero) does not fall within the intervals. Hence, H1, H2, H3, and $\mathrm{H} 4$ are supported. However, the effect sizes for most of the paths were small $\left(0.02<\mathrm{f}^{2}<\right.$ $0.15)$ except $\mathrm{PU} \rightarrow \mathrm{MP}\left(\mathrm{f}^{2}=0.305\right)$, which is moderate to large, as suggested by Cohen (1988).

Table 6

Structural model assessment and hypothesis testing

\begin{tabular}{llllll}
\hline Hypothesis & Path & $\beta$ & $\begin{array}{l}\text { Standard } \\
\text { Errors }\end{array}$ & $t$-value & p-value \\
\hline H1 & PU $\rightarrow$ MP & $0.460^{* * *}$ & 0.041 & 11.296 & 0.000 \\
H2 & PE $\rightarrow$ MP & $0.127 * * *$ & 0.048 & 2.651 & 0.008 \\
\hline
\end{tabular}


Table 6 (Continued)

\begin{tabular}{llllll}
\hline Hypothesis & Path & $\beta$ & $\begin{array}{l}\text { Standard } \\
\text { Errors }\end{array}$ & $t$-value & p-value \\
\hline H3 & PS $\rightarrow$ MP & $0.162 * * *$ & 0.047 & 3.444 & 0.001 \\
H4 & T $\rightarrow$ MP & $0.245^{* * *}$ & 0.055 & 4.492 & 0.000 \\
\hline
\end{tabular}

Notes: $* * * t$-values: $2.58(1 \%)$

Table 7

Structural model assessment and hypothesis testing (continue)

\begin{tabular}{llllll}
\hline Hypothesis & Path & \multicolumn{2}{l}{ Confidence Interval (95\%) } & $\begin{array}{l}\text { Effect Size } \\
\left(\mathrm{f}^{2}\right)\end{array}$ & Decision \\
\hline H1 & PU $\rightarrow$ MP & 0.373 & 0.543 & 0.305 & Supported \\
H2 & PE $\rightarrow$ MP & 0.042 & 0.218 & 0.022 & Supported \\
H3 & PS $\rightarrow$ MP & 0.072 & 0.250 & 0.037 & Supported \\
H4 & T $\rightarrow$ MP & 0.136 & 0.349 & 0.071 & Supported \\
\hline
\end{tabular}

\section{Partial Least Squares-Multiple Group Analysis (PLS-MGA)}

This research applied a non-parametric, or Henseler's, PLS-MGA to examine the categorical variables' moderating effects (i.e., gender, education level, and income). The subgroup of the doctoral respondents was discarded from the PLS-MGA analysis since it had only three respondents and caused a singular matrix error. Based on the guidelines provided by Henseler et al. (2009), if the $p$ value of the path coefficients is smaller than 0.05 or greater than 0.95 , then there is a significant difference between the groups. According to Table 8, the path coefficient of PU $\rightarrow$ MP for gender is significant, at a $5 \%$ error level, where the $p$ value is greater than 0.95 . Thus, there was a significant difference between the groups where the path coefficient for the females is significantly higher than the males. Next, the path coefficients of PU $\rightarrow$ MP showed that there were significant differences between groups of education (G2 is higher than G3) (see Table 8) and income (G1 is higher than G2 and G3) (see Table 9). However, the path coefficients of PS $\rightarrow$ MP indicated that there were significant differences between groups of education (G1 is higher than G4; G2 is higher than G3 and G4) (see Table 8). Finally, the results revealed that there were significant differences between groups of education (G1 is higher than G4; G3 is higher than G4) (see Table 8) for path $\mathrm{T} \rightarrow \mathrm{MP}$. Therefore, from the results of PLS-MGA, it can be concluded that H5a, $\mathrm{H} 5 \mathrm{~b}$, and $\mathrm{H} 5 \mathrm{c}$ are partially accepted. The results for path $\mathrm{PE} \rightarrow \mathrm{MP}$ did not indicate any significant difference between groups of gender, education, and income. 
Table 8

PLS-MGA results for education and gender groups

\begin{tabular}{llllllll}
\hline Path & $\begin{array}{l}p \text { value } \\
\text { (G1 vs }\end{array}$ & $\begin{array}{l}p \text { value } \\
\text { (G1 vs }\end{array}$ & $\begin{array}{l}p \text { value } \\
\text { (G1 vs }\end{array}$ & $\begin{array}{l}p \text { value } \\
\text { (G2 vs }\end{array}$ & $\begin{array}{l}p \text { value } \\
\text { (G2 vs }\end{array}$ & $\begin{array}{l}p \text { value } \\
\text { (G3 vs }\end{array}$ & $\begin{array}{l}p \text { value } \\
\text { (male vs } \\
\text { female) }\end{array}$ \\
\hline $\mathrm{G} 2)$ & $\mathrm{G} 3$ ) & $\mathrm{G} 4)$ & $\mathrm{G} 3$ ) & $\mathrm{G} 4)$ & G4) & 0.571 \\
$\mathrm{PE} \rightarrow \mathrm{MP}$ & 0.799 & 0.503 & 0.498 & 0.688 & 0.621 & 0.717 & 0.571 \\
$\mathrm{PS} \rightarrow \mathrm{MP}$ & 0.869 & 0.058 & $0.013^{*}$ & $0.034^{*}$ & $0.002^{*}$ & 0.063 & 0.554 \\
$\mathrm{PU} \rightarrow \mathrm{MP}$ & 0.373 & 0.651 & 0.868 & $0.023^{*}$ & 0.284 & 0.358 & $0.999^{*}$ \\
$\mathrm{~T} \rightarrow \mathrm{MP}$ & 0.431 & 0.137 & $0.024^{*}$ & 0.756 & 0.112 & $0.028^{*}$ & 0.944 \\
\hline
\end{tabular}

Notes: G1 (SPM certificate), G2 (Diploma), G3 (Bachelor's degree), G4 (Master's degree)

*Significant differences between groups at $5 \%$ error level $(p<0.05$ or $p>0.95)$

Table 9

PLS-MGA results for the income groups

\begin{tabular}{lllllll}
\hline Path & $\begin{array}{l}p \text { value } \\
\text { (G1 vs }\end{array}$ & $\begin{array}{l}p \text { value } \\
\text { (G1 vs }\end{array}$ & $\begin{array}{l}p \text { value } \\
\text { (G1 vs }\end{array}$ & $\begin{array}{l}p \text { value } \\
\text { (G2 vs }\end{array}$ & $\begin{array}{l}p \text { value } \\
\text { (G2 vs }\end{array}$ & $\begin{array}{l}p \text { value } \\
\text { (G3 vs }\end{array}$ \\
& $\mathrm{G} 2$ ) & $\mathrm{G} 3)$ & $\mathrm{G} 4)$ & $\mathrm{G} 3)$ & $\mathrm{G} 4)$ & $\mathrm{G} 4)$ \\
\hline $\mathrm{PE} \rightarrow \mathrm{MP}$ & 0.189 & 0.099 & 0.623 & 0.753 & 0.266 & 0.104 \\
$\mathrm{PS} \rightarrow \mathrm{MP}$ & 0.612 & 0.883 & 0.896 & 0.253 & 0.603 & 0.629 \\
$\mathrm{PU} \rightarrow \mathrm{MP}$ & $0.050^{*}$ & $0.011 *$ & 0.100 & 0.974 & 0.651 & 0.593 \\
$\mathrm{~T} \rightarrow \mathrm{MP}$ & 0.751 & 0.731 & 0.426 & 0.920 & 0.428 & 0.501 \\
\hline
\end{tabular}

Notes: G1 (RM1000 and below), G2 (RM1001-3000), G3 (RM3001-5000), G4 (RM5000 and above)

*Significant differences between groups at $5 \%$ error level $(p<0.05$ or $p>0.95)$

\section{DISCUSSION}

\section{Results Discussion}

According to the analytical results of this study, all predictor constructs are significantly related to the target construct. The finding of $\mathrm{PU} \rightarrow \mathrm{MP}(\beta=0.460, p<$ 0.01 ) concurs with the study of Leon (2018), which perceived usefulness was said to bring a more effective way to the users in making mobile payment if they understood the usefulness of the payment technology. Likewise, the statistical results also revealed that perceived ease of use was significantly associated with mobile payment adoption ( $\mathrm{PE} \rightarrow \mathrm{MP}, \beta=0.127, p<0.01)$. This finding supports the study of Teoh et al. (2013), who explained that mobile phone users usually corresponded to the ease of use of the services and minimal efforts required to perform transactions. To a certain extent, they found it easier to learn, use, and had control over the transaction processes. Next, the hypothesis testing results indicated that there is a significant association between perceived security and mobile payment adoption ( $\mathrm{PS} \rightarrow \mathrm{MP}, \beta=0.162, p<0.01$ ). 
This finding agrees with the studies of Seetharaman et al. (2017) and Khraim et al. (2011). These researchers provided empirical evidence to show that transaction information security generally guaranteed the system was safe in every transaction process. Nevertheless, the relationship between trust and mobile payment adoption was also found significant at the level of $1 \%$ ( $\mathrm{T} \rightarrow \mathrm{MP}, \beta=0.245, p<0.01$ ). This result is consistent with the research finding of Chanchai et al. (2016). They asserted that trust was a significant factor that could not be ignored in raising mobile payment adoption.

When investigating gender as a moderator, the PLS-MGA results show that females significantly moderated the path $\mathrm{PU} \rightarrow \mathrm{MP}, p=0.999$. This finding is in contrast to the studies of Venkatesh and Morris (2000) in which they found that males actually emphasized perceived usefulness when it came to mobile payment usage. However, our finding corroborates Goh and Sun's (2014) study, where they explained females were stronger than males in terms of perceived usefulness with regard to mobile payment. The plausible explanation for this finding is that females tend to use mobile payment because their level of consumption behavior is higher than males and they perceive mobile payment as highly convenient and useful (Susanto et al., 2016). Next, we examined the moderating role of education level toward mobile payment adoption. Education was found moderating most of the paths in the research model (i.e., $\mathrm{PS} \rightarrow \mathrm{MP}, \mathrm{PU} \rightarrow \mathrm{MP}, \mathrm{T} \rightarrow \mathrm{MP})$. According to the analysis results, it shows that less educated users are significantly higher than those educated urbanites in using mobile payment. This finding disagrees with the study of Cao et al. (2018), who discovered that educated users tended to use more mobile payment owing to their ability to use the mobile device and technology. Inconsistency of this result could be attributed to the mobile payment system design that is more user-friendly, easy-tolearn, and hassle-free for most of the less educated users (Pagani \& Schipani, 2008). Finally, the PLS-MGA results indicate that the lower income group (RM1000 and below) had higher perceived usefulness in using mobile payment rather than the other income groups (i.e., RM1001-RM3000 \& RM3001-RM5000). This unexpected finding goes against the study of Ansari and Farooqi (2017) who mentioned individuals with higher earnings were more inclined to use mobile payment. The possible reason for this finding is that lower income groups may have higher adaptability to digital payment technology and perceived it as an efficient tool for making payments (Teoh et al., 2013). As for path $\mathrm{PE} \rightarrow \mathrm{MP}$, there is no moderating effect detected. Thus, there is no difference between perceived ease of use and mobile payment adoption among the groups of respondents.

\section{Theoretical Implications}

Although there are numerous studies in the field mobile payment adoption, few have examined the moderating effects of demographic divides on mobile payment 
adoption in a developing country like Malaysia. This study attempts to examine the roles of gender, income, and education in understanding dissimilar patterns of urbanites in adopting mobile payment methods. The moderators were tested in a research model that integrated two wellknown theories of TAM and UTAUT. The results revealed that the proposed model has good explanatory power in predicting mobile payment adoption. For researchers, this study offers a basis in understanding how demographic divides affect the tendency of individuals to use mobile payment. Interestingly, some unexpected findings were discovered in this study; the lower income group has higher perceived usefulness in mobile payment, and less educated individuals are more likely to adopt mobile payment. These findings further confirmed that demographic divides lead to users' different behaviors and inclination to adopt new technology. Hence, this study provides new information for future researchers to include demographic factors as moderators in the research model when it comes to new technology adoption.

\section{Managerial Implications}

Based on the hypothesis testing results, perceived usefulness has the highest effect size at 0.305 . Therefore, managerial actions should focus on perceived usefulness in this aspect. When considering the importance of perceived usefulness, the functional design of mobile payment application should prioritize the usefulness of the intended service. Mobile payment service providers should establish strategies in delivering value propositions to the users that meet their needs, values, and lifestyle. Extraneous processes and procedures should be avoided to bring more effective ways in making transactions (Chen, 2008). Perhaps service providers and banking institutions should work together to provide extra benefits to the users, such as reduced transaction costs and guarantee return of payment if the transaction is wrongly made. Apart from that, timely notifications and accessibility to relevant information are crucial in providing the sense of usefulness to the users as they are fond of instant gratification. Immediate acknowledgment apparently satisfies the users' eagerness of efficient feedback. Additionally, the payment system interface should be designed in tandem with the functionality of the application as users are expecting the device to make their lives easier. Extra efforts should be given to young female users who are often receptive to new trends of payment and transactions. Service providers are also advised to keep users informed about the advantages and extra features of mobile payment and personalize it according to their preferences. Moreover, the government and service providers could actually focus on certain groups of users (i.e., females, less educated, low income) to increase the usage of mobile payment. Special efforts should also assess the needs of other non-active users, such as paying more attention to their feedback, concerns, and other obstacles that distance them from 
using mobile payment. The assessment outcome is essential to identify the causes of hesitancy among the potential users in using mobile payment (Rahman, 2015).

\section{CONCLUSION}

Theoretically, this study has successfully examined the impact of demographic divides on mobile payment adoption in Malaysia. It highlights the moderating effects of gender, income, and education on the relationship between the determining factors and mobile payment adoption. Practically, it pinpoints perceived usefulness as the most important predictor construct for managerial actions. Thus, related parties, like banking institutions, mobile service providers, and the government should articulate the usefulness of mobile payment consistently to gain more participants in this payment technology. The findings of this study also suggest that focusing on the significant groups based on the moderating results should be able to increase the number of mobile payment users in the future.

\section{Limitations and Future Research}

This study has some limitations that need to be considered for future research. First, this study examined the adoption of mobile payment specifically among the urbanites community. The samples obtained cannot be generalized toward the rural population. It is suggested that future research should consider including rural areas as a research population. Second, the study was conducted in Malaysia; the findings may not be generalizable to other countries. Future studies may attempt to broaden the research scope across countries and conduct a comparative study. Third, the predictor constructs extracted from TAM and UTAUT in this study may not be adequate in predicting mobile payment adoption. Future researchers may consider using other predictor constructs, such as service quality, system quality, users' needs, and satisfaction to increase the research model's predictability.

\section{ACKNOWLEDGEMENTS}

The authors wish to thank the Malaysian Ministry of Higher Education and Universiti Teknologi Malaysia (GUP Tier 2: 15J99) for providing financial support to publish this paper.

\section{REFERENCES}

Abeer, M., Habib, U. K., \& Khaled, A. A. (2015). Factors influence consumers' adoption of mobile payment devices in Qatar. International Journal of Mobile Communication, 13(6), 670-689. doi. org/10.1504/ijmc.2015.072100

Ansari, S., \& Farooqi, R. (2017). Moderating effect of demographic variables on attitude towards online shopping: An empirical study using PROCESS. IOSR Journal of Business and Management, 19(11), 47-54.

Aydin, G., \& Burnaz, S. (2016). Adoption of mobile payment systems: A study on mobile wallets. Journal of Business, Economics and Finance, 5(1), 73-92. doi.org/10.17261/ pressacademia.2016116555

Bem, S. L. (1981). The BSRI and gender schema theory: A reply to Spence and Helmreich. Psychological Review, 88(4), 369-371. doi. org/10.1037/0033-295x.88.4.369 
Bhattacherjee, A. (2001). Understanding information systems continuance: An expectationconfirmation model. MIS Quarterly, 25(3), 351-370. doi: $10.2307 / 3250921$

Cao, X., Yu, L., Liu, Z., Gong, M., \& Adeel, L. (2018). Understanding mobile payment users' continuance intention: A trust transfer perspective. Internet Research, 28(2), 456-476. doi: 10.1108/intr-11-2016-0359

Chanchai, P., Carmine, S., \& Michelle W. L. F. (2016). An investigation of mobile payment (m-payment) services in Thailand. Asia-Pacific Journal of Business Administration, 8(1), 37-54. doi: 10.1108/apjba-10-2014-0119

Chau, P. Y. K. (1996). An empirical assessment of a modified technology acceptance model. Journal of Management Information Systems, 13(2), 185-204. doi: 10.1080/07421222.1996.11518128

Chen, L. (2008). A model of consumer acceptance of mobile payment. International Journal of Mobile Communications, 6(1), 32-52. doi: 10.1504/ ijmc.2008.015997

Chen, Y.-H., \& Barnes, S. (2007). Initial trust and online buyer behavior. Industrial Management \& Data Systems, 107(1), 21-36. doi: $10.1108 / 02635570710719034$

Cheng, Y.-M. (2011). Antecedents and consequences of e-learning acceptance. Information Systems Journal, 21(3), 269-299. doi: 10.1111/j.13652575.2010.00356.x

Chin, W. W. (2010). How to write up and report PLS analyses. In V. E. Vinzi, W. W. Chin, J. Henseler \& H. Wang (Eds.), Handbook of Partial Least Squares: Concepts, Methods and Applications in Marketing and Related Fields (pp. 655-690). Berlin, Germany: Springer. doi: 10.1007/978-3540-32827-8_29

Chua, C.-J., Lim, C.-S., \& Aye, A. K. (2020). Consumers' behavioural intention to accept of the mobile wallet in Malaysia. Journal of
Southwest Jiaotong University, 55(1), 1-13. doi.: 10.35741/issn.0258-2724.55.1.3

Cohen, J. (1988). Statistical power analysis for the behavioral sciences (2nd ed.). New Jersey, USA: Lawrence Earlbaum Associates.

Cohen, J. (1992). A power primer. Psychological Bulletin, 112, 155-159. doi: 10.1037/00332909.112.1.155

Dastan, I., \& Gürler, C. (2016). Factors affecting the adoption of mobile payment systems: An empirical analysis. Emerging Markets Journal, 6(1), 17-24. doi: 10.5195/emaj.2016.95

Davis, F. D. (1989). Perceived usefulness, perceived ease of use, and user acceptance of information technology. MIS Quarterly, 13(3), 319-340. doi: $10.2307 / 249008$

Davis, F. D., Bagozzi, R., \& Warshaw, P. (1989). User acceptance of computer-technology - a comparison of 2 theoretical-models. Management Science, 35(8), 982-1003. doi: 10.1287/mnsc.35.8.982

Department of Statistics Malaysia. (2019). Demographic Statistics First Quarter (Q1) 2019, Malaysia. Retrieved June 1, 2019, from https://www.dosm.gov.my/v1/index.php/ index.php?r=column/ctwoByCat\&parent_ id=115\&menu_id=L0pheU43NWJwRWVSZkl WdzQ4TlhUUT09

Dwivedi, Y. K., Rana, N. P., Chen, H., \& Williams, M. D. (2011). A meta-analysis of the Unified Theory of Acceptance and Use of Technology (UTAUT). In M. Nüttgens, A. Gadatsch, K. Kautz, I. Schirmer, \& N. Blinn (Eds.), Governance and Sustainability in Information Systems. Managing the Transfer and Diffusion of IT. Berlin, Germany: Springer. doi: 10.1007/978-3642-24148-2_10

Escobar-Rodriguez, T., Monge-Lozano, P., \& Romero-Alonso, M. M. (2012). Acceptance of e-prescriptions and automated medication- 
management systems in hospitals: An extension of the technology acceptance model. Journal of Information Systems, 26(1), 77-96. doi: 10.2308/ isys- 10254

Fitch Solutions: Malaysians still prefer cash to cashless transactions. (2019, July 31). The Star. Retrieved August 1, 2019, from https://www.thestar. com.my/business/business-news/2019/07/31/ fitch-solutions-malaysians-still-prefer-cash-tocashless-transactions

Gefen, D. (2000). E-Commerce: The role of familiarity and trust. The International Journal of Management Science, 28(6), 725-737. doi: 10.1016/s0305-0483(00)00021-9

Goh, T. T., \& Sun, S. (2014). Exploring gender differences in Islamic mobile banking acceptance. Electronic Commerce Research, 14(4), 435-458. doi: 10.1007/s10660-014-9150-7

Hair Jr., J. F., Hult, G. T. M., Ringle, C., \& Sarstedt, M. (2017). A primer on partial least squares structural equation modelling (PLS-SEM). California, USA: Sage Publications.

Henseler, J., Ringle, C. M., \& Sarstedt, M. (2014). A new criterion for assessing discriminant validity in variance-based structural equation modelling. Journal of the Academy of Marketing Science, 43(1), 115-135. doi: 10.1007/s11747-014-0403-8

Henseler, J., Ringle, C. M., \& Sinkovics, R. R. (2009). The use of partial least squares path modelling in international marketing. In R. R. Sinkovics \& P. N. Ghauri (Eds.), Advances in International Marketing (Vol. 20; pp. 277-319). doi: 10.1108/ S1474-7979(2009)0000020014

Hu, P. J., Chau, P. Y. K., Sheng, O. R. L., \& Tam, K. Y. (1999) Examining the technology acceptance model using physician acceptance of telemedicine technology. Journal of Management Information Systems, 16(2), 91112. doi: 10.1080/07421222.1999.11518247
Jung, J.-Y., Qiu, J. L., \& Kim, Y.-C. (2001). Internet connectedness and inequality: Beyond the “divide". Communication Research, 28(4), 507525. doi: 10.1177/009365001028004006

Khraim, H. S., Al Shoubaki, Y. E., \& Khraim, A. S. (2011). Factors affecting Jordanian consumers' adoption of mobile banking services. International Journal of Business and Social Science, 2(20), 96-105.

Kock, N. (2015). Common method bias in PLSSEM: A full collinearity assessment approach. International Journal of e-Collaboration (IJeC), 11(4), 1-10. doi: 10.4018/ijec.2015100101

Kurnia, S., \& Benjamin, L. (2007). Exploring the reasons for a failure of electronic payment systems a case study of an Australian company. Journal of Research and Practice in Information Technology, 39(4), 34-67.

Leon, S. (2018). Service mobile apps: A millennial generation perspective. Industrial Management \& Data Systems, 118(9), 1837-1860. doi: 10.1108/imds-10-2017-0479

Linck, K., Pousttchi, K., \& Wiedemann, D. G. (2006). Security issues in mobile payment from the customer viewpoint. In J. Ljungberg (Ed.), Proceedings of the 14th European Conference on Information Systems (ECIS 2006) (pp. 1-11). Göteborg, Sweden.

Liu, G., \& Tai, P. T. (2016). A study of factors affecting the intention to use mobile payment services in Vietnam. Economics World, 4(6), 249-273. doi: $10.17265 / 2328-7144 / 2016.06 .001$

Lwoga, E. T., \& Lwoga, N. B. (2017). User acceptance of mobile payment: The effects of user-centric security, system characteristics and gender. Electronic Journal of Information Systems in Developing Countries, 81(1), 1-24. doi: 10.1002/ j.1681-4835.2017.tb00595.x 
Mahad, M., Mohtar, S., \& Othman, A. A. (2015). The effect of perceived trust of mobile banking services in Malaysia, International Academic Research Journal of Business and Technology, 1(7), 1-7.

Martin, B. (2019, July 12). Please leave your wallet at home. The Star. Retrieved August 1, 2019, from https:/www.thestar.com.my/opinion/columnists/ on-your-side/2019/07/12/please-leave-yourwallet-at-home

Mondego, D., \& Gide, E. (2018). The effect of trust on mobile payment adoption: A comprehensive review of literature. International Journal of Arts and Sciences, 11(1), 375-390.

Mossberger, K., Tolbert, C. J., \& Gilbert, M. (2006). Race, place and information technology. Urban Affairs Review, 41(5), 583-620. doi: $10.1177 / 1078087405283511$

Ndubisi, N. O., \& Jantan, M. (2003). Evaluating IS usage in Malaysian small and mediumsized firms using TAM. Logistics Information Management, 16(6), 440-450. doi: $10.1108 / 09576050310503411$

Ng, I. C. L., \& Yip, N. K. T. (2010). Theoretical foundations in the pricing of intermediating services: The case of payments via mobile phones. Journal of Revenue and Pricing Management, 9(3), 217-227. doi: 10.1057/ rpm.2010.6

Pagani, M., \& Schipani, D. (2008). Motivations and barriers to the adoption of $3 \mathrm{G}$ mobile multimedia services: An end-user perspective in the Italian market. In S. R. Rahman (Ed.). Multimedia Technologies: Concepts, Methodologies, Tools, and Applications (pp. 182-192), Boston, USA.

Pavlou, P. (2003). Consumer acceptance of electronic commerce: Integrating trust and risk with the technology acceptance model. International Journal of Electronic Commerce, 7(3), 101-134. doi: 10.1080/10864415.2003.11044275
Preacher, K. J., \& Hayes, A. F. (2008). Asymptotic and resampling strategies for assessing and comparing indirect effects in multiple mediator models. Behavioral Research Methods, 40(3), 879-891. doi: 10.3758/brm.40.3.879

Quibra, M., Ahmed, S. N., Tschang, T., \& ReyesMacasaquit, M.-L. (2003). Digital divide: Determinants and policies with special reference to Asia. Journal of Asian Economics, 13(6), 811- 825. doi: 10.1016/s1049-0078(02)00186-0

Rahi, S., \& Abd Ghani, M. (2018). The role of UTAUT, DOI, perceived technology security and game elements in internet banking adoption. World Journal of Science, Technology and Sustainable Development, 15(4), 338-356. doi: 10.1108/wjstsd-05-2018-0040

Rahman, A. (2015). Toward a comprehensive conceptualization of digital divide and its impact on e-government system success. Advances in Business Marketing and Purchasing, 23A, 291488. doi: 10.1108/s1069-096420150000023003

Ramayah, T., \& Suki, N. M. (2006). Intention to use mobile PC among MBA students: Implications for technology integration in the learning curriculum. UNITAR e-Journal, 1(2), 1-10.

Rehman, Z. U., \& Zabri, S. B. M. (2020). Determinants of mobile banking adoption in Malaysia: A conceptual framework. Journal for Studies in Management and Planning, 4(13), 260-270.

Rosen, L. D., \& Maguire, P. (1990). Myths and realities of computer phobia: A meta-analysis. Anxiety Research: An International Journal, 3(3), 175191. doi: 10.1080/08917779008248751

Saunders, M., Lewis, P., \& Thornhill, A. (2009). Research methods for business students (5th ed). Essex, England: Pearson.

Schierz, P. G., Schilke, O., \& Wirtz, B. W. (2010). Understanding consumer acceptance of mobile payment services: An empirical analysis. Electronic Commerce Research and Applications, 
9(3), 209-216. doi: 10.1016/j.elerap.2009.07.005

Seetharaman, A., Kumar, K. N., Palaniappan, S., \& Weber, G. (2017). Factors influencing behavioral intention to use the mobile wallet in Singapore. Journal of Applied Economics and Business Research, 7(2), 116-136.

Shiveen, A., \& Rahela, F. (2017). Moderating effect of demographic variables on attitude towards online shopping: An empirical study using PROCESS. IOSR Journal of Business and Management, 19(11), 47-54.

Singh, G. (2019). A review of factors affecting digital payments and adoption behaviour for mobile e-wallets. International Journal of Research in Management \& Business Studies, 6(4), 89-96.

Surendran, P. (2012). Technology acceptance model: A survey of literature. International Journal of Business and Social Research, 2(4), 175-178.

Susanto, A., Chang, Y., \& Ha, Y. (2016). Determinants of continuance intention to use the smartphone banking services. Industrial Management \& Data Systems, 116(3), 508-525. doi: 10.1108/ imds-05-2015-0195

Teoh, C., \& Md Nor, K. (2007). Consumer acceptance of mobile banking. Journal of Technology Management and Entrepreneurship, 6, 1-17.

Teoh, W. M. Y., Chong, S. C., \& Chua, J. W. (2013). Factors affecting consumers' perception of electronic payment: An empirical analysis. Internet Research, 23(4), 465-485. doi: 10.1108/ intr-09-2012-0199

Tey, N. P., Lai, S. L., \& Azlina, I. N. (2019). Population situation analysis Malaysia 2018, Kuala Lumpur, Malaysia. Retrieved August 1, 2019, from https:// umexpert.um.edu.my/file/ publication/00006585_170038_82296.pdf

Trivedi, J. (2016). Factors determining the acceptance of e-wallets. International Journal of Applied Marketing and Management, 1(2), 42-53.
Tsiakis, T., \& Sthephanides, G. (2005). The concept of security and trust in e-payments. Computers and Security, 24(1), 10-15. doi: 10.1016/j. cose.2004.11.001

Van der Heijden, H. (2004). User acceptance of hedonic information systems. MIS Quarterly, 28(4), 695-704. doi: 10.2307/25148658

Venkatesh, V. (2000). Determinants of perceived ease of use: Integrating control, intrinsic motivation, and emotion into the technology acceptance model. Information Systems Research, 11(4), 342-365. doi: 10.1287/isre.11.4.342.11872

Venkatesh, V., \& Bala, H. (2008). Technology acceptance model 3 and a research agenda on interventions. Decision Sciences, 39(2), 273-315. doi: 10.1111/j.1540-5915.2008.00192.x

Venkatesh, V., \& Davis, F. D. (2000). A theoretical extension of the technology acceptance model: four longitudinal field studies. Management Science, 46(2), 186-204. doi: 10.1287/ mnsc.46.2.186.11926

Venkatesh, V., \& Morris, M. (2000). Why don't men ever stop to ask for directions? Gender, social influence, and their role in technology acceptance and usage behavior. MIS Quarterly, 24(1), 115139. doi: $10.2307 / 3250981$

Venkatesh, V., Morris, M., Davis, G., \& Davis, F. (2003). User acceptance of information technology: Toward a unified view. MIS Quarterly, 27(3), 425-478. doi: 10.2307/30036540

Vijayasarathy, L. R. (2004). Predicting consumer intentions to use online shopping: The case for an augmented technology acceptance model. Information and Management, 41(6), 747-762. doi: 10.1016/j.im.2003.08.011

Wang, N., Shen, X. L., \& Sun, Y. Q. (2013). Transition of electronic word-of-mouth services from web to mobile context: A trust transfer perspective. Decision Support Systems, 54(3), 1394-1403. doi: 10.1016/j.dss.2012.12.015 
Wang, W. T., \& Li, H. M. (2011). Factors influencing mobile services adoption: A brand-equity perspective. Internet Research, 22(2), 142-179. doi: $10.1108 / 10662241211214548$

Wei, T. T., Marthandan, G., Chang, A. Y.-L., Ooi, K.-B., \& Arumugam, S. (2009). What drives Malaysian m-commerce adoption? An empirical analysis. Industrial Management and Data Systems, 109(3), 370-388. doi: $10.1108 / 02635570910939399$

Wong, K. K.-K. (2013). Partial least squares structural equation modeling (PLS-SEM) techniques using SmartPLS. Marketing Bulletin, 24(1), 1-32.

Xin, H., Techatassanasoontorn, A. A., \& Tan, F. B. (2013). Exploring the influence of trust on mobile payment adoption. PACIS 2013 Proceedings. Paper 143. Retrieved June 1, 2019, from https:// core.ac.uk/download/pdf/56363727.pdf

Yang, Q., Pang, C., Liu, L., Yen, D.C., \& Michael Tarn, J. (2015). Exploring consumer perceived risk and trust for online payments: An empirical study in China's younger generation. Computers in Human Behavior, 50(September), 9-24. doi: 10.1016/j.chb.2015.03.058
Yap, C-M., \& Ng, B-A. (2019). Factors influencing consumers' perceived usefulness of m-wallet in Klang Valley, Malaysia. Review of Integrative Business and Economics Research, 8(4), 1-23.

Yenisey, M. M., Ozok, A. A., \& Salvendy, G. (2005). Perceived security determinants in e-commerce among Turkish university students. Behavioural and Information Technology, 24(4), 259-274. doi: 10.1080/0144929042000320992

Yu, C.-S. (2012). Factors affecting individuals to adopt mobile banking: Empirical evidence from the UTAUT model. Journal of Electronic Commerce Research, 13(2), 104-121.

Zhou, T. (2011). An empirical examination of initial trust in mobile banking. Internet Research, 21(5), 527-540. doi: 10.1108/10662241111176353 


\section{APPENDIX}

\section{Measures for the study constructs}

\begin{tabular}{|c|c|c|}
\hline Construct & Measures & Source \\
\hline $\begin{array}{l}\text { Mobile } \\
\text { Payment } \\
\text { Adoption } \\
\text { (MP) }\end{array}$ & $\begin{array}{l}\text { I am willing to adopt mobile payment in the near } \\
\text { future. } \\
\text { Given a chance, I intend to adopt mobile payments in } \\
\text { the future. } \\
\text { I foresee that I will adopt mobile payment services in } \\
\text { the next } 6 \text { months. } \\
\text { I plan to adopt mobile payment as soon as possible. } \\
\text { I prefer to use mobile payment than any other } \\
\text { payment method in the future. } \\
\text { I will strongly recommend mobile payment to my } \\
\text { friends. }\end{array}$ & $\begin{array}{l}\text { Venkatesh and } \\
\text { Davis (2000), } \\
\text { Xin et al. (2013), } \\
\text { Liu and Tai (2016). }\end{array}$ \\
\hline $\begin{array}{l}\text { Perceived } \\
\text { Usefulness } \\
\text { (PU) }\end{array}$ & $\begin{array}{l}\text { Mobile payment is useful for me to pay for products } \\
\text { or services. } \\
\text { Mobile payment makes it efficient for me to pay for } \\
\text { products or services. } \\
\text { Mobile payment saves my time for products or } \\
\text { services payment. } \\
\text { Mobile payment makes it convenient for me to make } \\
\text { payment. } \\
\text { I find mobile payment is very effective in making } \\
\text { transaction. } \\
\text { Mobile payment requires less effort and time } \\
\text { compared to conventional payment methods. }\end{array}$ & $\begin{array}{l}\text { Bhattacherjee } \\
\text { (2001), Van der } \\
\text { Heijden (2004). }\end{array}$ \\
\hline $\begin{array}{l}\text { Perceived } \\
\text { Ease of Use } \\
(\mathrm{PE})\end{array}$ & $\begin{array}{l}\text { It is easy to learn how to use mobile payment. } \\
\text { When using mobile payment, it rarely confused me. } \\
\text { It is clear and understandable to use mobile payment. } \\
\text { I have no difficulty to use mobile payment. } \\
\text { When using mobile payment, I rarely make mistakes. } \\
\text { When using mobile payment, I rarely get frustrated. }\end{array}$ & Trivedi (2016) \\
\hline $\begin{array}{l}\text { Perceived } \\
\text { Security } \\
\text { (PS) }\end{array}$ & $\begin{array}{l}\text { It is secured to provide sensitive information over the } \\
\text { mobile payment services. } \\
\text { It is safe to provide personal information over the } \\
\text { mobile payment services. } \\
\text { I have confidence in using mobile payment because } \\
\text { third parties are not allowed to gain access to my } \\
\text { account. } \\
\text { I find it secured to conduct transactions over mobile } \\
\text { payment system. } \\
\text { I have confidence and without fear to use my credit } \\
\text { card over mobile payment system. } \\
\text { I believe transaction information over mobile } \\
\text { payment will not be used by irresponsible parties. }\end{array}$ & $\begin{array}{l}\text { Lwoga and Lwoga } \\
\text { (2017), Aydin and } \\
\text { Burnaz (2016), } \\
\text { Yenisey et al. } \\
\text { (2005). }\end{array}$ \\
\hline
\end{tabular}




\section{APPENDIX (Continued)}

\begin{tabular}{lll}
\hline Construct & Measures & Source \\
\hline Trust (T) & Mobile payment service providers always & Lwoga and Lwoga \\
& provide accurate financial update. & (2017), Xin et al. (2013), \\
& Mobile payment service providers always & Pavlou (2003). \\
& provide reliable financial services. & \\
& Mobile payment service providers always & \\
safeguard financial information. & \\
& I believe mobile payment services. & \\
& I trust mobile payment services. \\
& I believe mobile payment service providers are \\
& & \\
\hline
\end{tabular}

